\title{
Consumer Bankruptcy and Default: The Role of Individual Social Capital Formation Characteristics*
}

\author{
Sumit Agarwal ${ }^{\mathrm{a}}$, Souphala Chomsisengphet ${ }^{\mathrm{b}}$, and Chunlin Liu ${ }^{\mathrm{c}}$
}

First draft: February 22, 2007

This version: March 2, 2008

\begin{abstract}
An individual's decision to maximize his investment in social capital is determined by his socio-economic characteristics, such as homeownership and mobility (Glaeser, Laibson and Sacerdote, 2002). In this paper, we empirically assess the role of individual social capital formation characteristics on personal bankruptcy and default outcomes in the consumer credit market. After controlling for a borrower's risk score, debt, income, wealth as well as legal and economic environments, we find that default/bankruptcy risk rises and then falls over the lifecycle, while a borrower who owns a home or is married has a lower risk of default/bankruptcy. Moreover, a borrower who migrates 325 miles from his "state of birth" is 26 percent more likely to default and 28 percent more likely to file for bankruptcy, while a borrower who continues to live in his state of birth is 14 and 10 percent less likely to default and file for bankruptcy, respectively. Finally, a borrower who moves to a rural area is 9 and 7 percent less likely to default and declare bankruptcy, respectively.
\end{abstract}

JEL Classification: D1; D8; G2

Key Words: Social Capital; Consumer Bankruptcy; Default; Credit Risk; Credit Cards; Banking.

\footnotetext{
*The authors thank Lauren Gaudino, Cosmin Lucaci, and Regina Villasmil for excellent research assistance and Carrie Jankowski for providing the Census data. We also thank Gadi Belreve, Luca Benzoni, Bert Higgins, Anna Paulson and David Laibson for helpful discussions, comments and suggestions. The views expressed in this research are those of the authors and do not necessarily represent the policies or positions of the Office of the Comptroller of the Currency, the U.S. Treasury Department, the Federal Reserve Bank of Chicago, or the Board of Governors of the Federal Reserve System. Liu gratefully acknowledges the financial support from the University of Arizona's Take Charge American Institute.

${ }^{a}$ Federal Reserve Bank of Chicago, sagarwal@chi.frb.org

${ }^{\mathrm{b}}$ Office of the Comptroller of the Currency, souphala.chomsisengphet@occ.treas.gov

c Finance Department, University of Nevada-Reno, liuc@unr.edu
} 


\section{Introduction}

Sociologists define social capital as the social networks, norms, cooperation and trusts created by human interactions in a community (see e.g., Putnam, 1995 and 2000). Accordingly, community engagement, e.g., voter turnout at referenda or membership in a non-profit organization, generates positive externalities. Conventional economic theory suggests that social interactions play a role in repeated games (Abreu, 1988), contract theory (Arrow, 1972), and solving free rider problems (Greif, 1993). Studies have found that communities with higher social capital enjoy higher economic growth (Knack and Keefer, 1997) and greater judicial efficiency and lower corruption (LaPorta, Lopez-de-Silanes, Shliefer and Vishny, 1997).

More recently, Glaeser, Laibson, and Sacerdote (2002) contend that decisions to optimally invest in social capital (as in human capital) are determined by individuals, and individual social capital formation is then aggregated up to the community-level. In their framework of economic behaviors, an individual maximizes the returns to his investment in social capital; such investment decision is determined by the socio-economic characteristics of that individual. For instance, homeownership increases neighborhood social capital investment because homeowners face high real estate transaction costs (which reduces mobility) and have a financial incentive to increase their property value (see also DiPasquale and Glaeser, 1998). Furthermore, the return to social capital investment depreciates when one moves out of a community; thus, mobility reduces the individual's investment in social capital of a community. ${ }^{1}$

In this paper, we empirically assess the role of individual social capital formation characteristics on household default and bankruptcy outcomes. We estimate a Cox proportional hazard model using a loan-level monthly panel data of more than 170,000 credit cardholders over a

\footnotetext{
${ }^{1}$ Frequent mobility also weakens social connection (see e.g., Glaeser and Sacerdote, 1999) and reduces reputational concerns (see e.g., Buckley and Brinig, 2000).
} 
24-month period. In our data, we observe a borrower's default and bankruptcy filing status in each month over our sample period as well as a borrower's socio-economic characteristics (e.g., age, marital status and homeownership status). In addition, we also have information that enables us to control for important financial distress factors that are predicted to drive a borrower into default to bankruptcy, such as a borrower's "riskiness", spending, debt, income, wealth as well as economic conditions and legal environment. Moreover, our data is also unique in that there's information about an individual's current county of residence and his state of birth (or state of immigration entry for foreign born), allowing us to identify mobility for each borrower. Thus, in addition to age, marital status as well as homeownership status, our individual social capital formation characteristics also include: whether a borrower still lives in his "state of birth"; the distance in miles between his state of residence and state of birth; and whether a borrower has migrated to a rural area. Based on the individual social capital formation economic model of Gleaser, Laibson and Sacerdote (2002), we expect the risk of default or bankruptcy to be lower for a borrower who has greater incentive to invest in social capital.

Previewing the results, our findings indicate that living in worsening local unemployment condition and in a state without health insurance coverage play a statistically and economically significant role in consumer default and bankruptcy. Moreover, we also find that credit risk deterioration, lower income and wealth status, as well as higher spending, APR or debt significantly increases a borrower's risk of defaulting on his debt or declaring bankruptcy. Overall, these financial distress factors of consumer default or bankruptcy risk are documented in Domowitz and Sartain (1999), Sullivan, Warren and Westbrook (2000), Gross and Souleles (2002) and in the quantitative theoretical model of Chatterjee, Corbae, Nakajima and Rios-Rull (2007). 
After controlling for an individual's credit risk score, spending, debt, income and wealth as well as macroeconomic conditions and legal variations across states, we find that individual social capital formation characteristics can significantly explain consumer bankruptcy and default outcomes. First, we find that the risk of bankruptcy and default is higher for an individual who migrates out of his state of birth. For example, an individual who continues to live in his state of birth is 9 percent less likely to default on his credit card debt and 13 percent less likely to file for bankruptcy, while an individual who moves 325 miles from his state of birth is 26 percent more likely to default and 28 percent more likely to declare bankruptcy. Furthermore, compared to individuals who move to an urban area, those who move to a rural area are 9 and 7 percent less likely to default and declare bankruptcy, respectively. These results are consistent with our expectation based on the individual social capital formation economic model by Glaeser et al (2002).

Furthermore, we also find that defaults and bankruptcies rise and then fall over the lifecycle. Equally important, a borrower who is married is 24 percent less likely to default on his credit card debt and 32 percent less likely to file for bankruptcy. Finally, an individual who owns a home is 17 and 25 percent less likely to, respectively, default and file for bankruptcy.

Our findings may also have some implications for the ongoing debate surrounding the rise in consumer bankruptcy over the past almost two decades. Sullivan, Warren and Westbrook (2000) show evidence of two major causes of the recent increase in bankruptcy filings in the US: increases in credit card and mortgage debt; and unexpected adverse events (such as unemployment, divorce, health problems, medical debts) have reduced the ability of households to repay their debt and eventually compel them to file for bankruptcy. ${ }^{2}$ Despite such compelling evidence, many contend

\footnotetext{
${ }^{2}$ See also Domowitz and Sartain (1999) and Barron, Elliehausen, and Staten (2000). Hence, Chatterjee, Corbae, Nakajima and Rios-Rull (2007) incorporates simultaneously the role of household earnings, unsecured debt as well as shocks to earnings, debt and preference shocks (e.g., divorce) in their theoretical household default/bankruptcy dynamic equilibrium model.
} 
that increases in debt and adverse income or spending shocks cannot entirely explain the rise in consumer bankruptcy over the past almost two decades.

Fay, Hurst and White (2002) show that state bankruptcy exemption creates financial gains for debtors to file for bankruptcy and in turn, induces households to strategically default. ${ }^{3}$ Using a panel of individual credit card accounts and controlling for individual risk composition and economic environments, Gross and Souleles (2002) find that credit cardholders in 1997 are 1 percentage point more likely to file for bankruptcy than individuals with similar characteristics in 1995, suggesting that their finding is perhaps due to a decline in the cost of bankruptcy such as a decline in social stigma attached to bankruptcy due to changing social norms. Fay, Hurst and White (2002) also suggest a decline in social stigma to explain their finding of a higher risk of bankruptcy filing for households living in districts with higher aggregate bankruptcy filing rates. Other studies suggesting that the decline in social stigma can partially explain the recent rise in bankruptcy include empirical evidence of Buckley and Brinig (1998) at the state-level and predictions in the equilibrium bankruptcy model of Livshits, MacGee and Tertilt (2007). ${ }^{4}$

After controlling for a borrower's credit riskiness, spending, debt, income, and wealth as well as legal and economic environments, our study may provide additional insights to the role of social stigma on consumer bankruptcy. Mobility weakens an individual's investment in social capital (DiPasquale and Glaeser, 1998; Glaeser, Laibson and Sacerdote, 2002) and reduces reputational concerns (Buckley and Brinig, 2000), while rural areas or small town communities have stronger social norms due to homogeneity (Alesina and LaFerrara, 2000) and face higher cost of

\footnotetext{
${ }^{3}$ Gropp, Scholz and White (1997) also show that debtors are more likely to file for bankruptcy and repay less in bankruptcy as bankruptcy exemption level rises. They also argue that the exemption laws provide partial wealth insurance and the insurance coverage rises with the exemption levels. See also Agarwal, Liu, and Mielnicki (2003) and Agarwal, Chomsisengphet, Liu, and Mielnicki (2005) for empirical evidence on the impact of bankruptcy exemptions on, respectively, consumer and small business bankruptcy.

${ }^{4}$ However, in the model of Arthreya (2004), a decline in social stigma cannot explain the simultaneous increase in both debt and bankruptcy. Athreya (2004) and Livshits, MacGee and Tertilt (2007) also attribute the recent increase in bankruptcy filing to lower transaction cost of lending.
} 
social connection due to greater distance (Galeser and Sacerdote, 2000). These individual socioeconomic characteristics collectively can affect the strength of social networks and norms in a community and in turn shape the degree of a community's attitude towards certain behaviors or outcomes. In this study, we show the explanatory significance of an individual's social capital formation characteristics on his propensity to default on his debt or file for bankruptcy, ceteris paribus. Such characteristics can in turn influence a community to attach social stigma to personal bankruptcy and default.

A parallel study which directly assesses the impact of state-level social capital characteristics on aggregate consumer bankruptcy is that of Buckley and Brinig (1998), who find that the rise in bankruptcy filings of 86 federal judicial districts over the 1980-1991 period can be attributed to higher per capital interstate migration into a state plus inter-county migration within a state and smaller percent of population living in metropolitan statistical area. Thus by providing evidence on the explanatory significance of individual social capital formation characteristics on household default and bankruptcy outcomes, our study nicely complements that of Buckley and Brinig.

We also assess the correlation between Putnam's state social capital index (Putnam 2000) and state bankruptcy filing rate in 2000. We find that states that are ranked higher on Putnam's social capital index (e.g., Vermont and Minnesota) have lower bankruptcy filing rate, while states that are ranked lower on the social capital index (e.g., Georgia and Tennessee) have higher bankruptcy rate. Controlling for variations in unemployment conditions, percentage of state population without health insurance coverage and state bankruptcy laws, we find that states with a 1point lower social capital index face a 0.3 percentage point higher state bankruptcy rate per capita.

Finally, our paper also contributes to the literature studying the impact of social capital on household financial decision-making. Madrian and Shea (2001) find that an individual's decision to 
participate in a particular employer-sponsored retirement plan is influenced by the choices of their co-workers. Guiso, Sapienza and Zingales (2004) find that Italian households in regions with higher social capital are more likely to use formal credit channels, such as writing more checks and investing in stocks. Hong, Kubik, and Stein (2004) show that people who attend church and interact with their neighbors are more likely to invest in the stock market.

The paper proceeds as follows. Section 2 describes our data and empirical methodology. Section 4 discusses the empirical results, and section 5 concludes.

\section{Data and Methodology}

\subsection{Data}

We use a proprietary 24-month panel dataset from a large financial institution that issues credit cards nationally. There are several unique and important features of this data set that enables us to test the impact of individual social capital variables on consumer bankruptcy and default. This data set includes a representative sample of more than 170,000 individual credit card accounts that were issued between January 1997 and June 2000.

For each credit cardholder, we observe his repayment or bankruptcy status each month from June 2000 to June 2002. If an account is 90-days past due in any given month over our 24-month sample period, a delinquency flag was created for that account. If the account was in formal bankruptcy at any time, a bankruptcy flag was created for that account. Since a cardholder can declare bankruptcy before they are 90 -days delinquent (approximately $20 \%$ - 30\% do so), the model captures individuals that are either delinquent or delinquent and have declared bankruptcy. ${ }^{5}$ Hence for the rest of the paper, whenever we refer to an account being 90-days delinquent (i.e., default), we do include accounts that declared bankruptcy prior to being delinquent. Furthermore, accounts with

\footnotetext{
${ }^{5}$ The results for the default analysis are qualitative the same when we exclude the bankruptcy accounts.
} 
a flag indicating lost, stolen, never active, closed due to fraud/death status are excluded from the analysis.

We also have additional important information that has been found to predict default or bankruptcy outcomes, such as the cardholder's monthly credit limit, spending balance, credit card debt as well as other debt (which includes mortgage, home equity or auto balance). We also know each cardholder's credit bureau risk score (FICO score), which is updated quarterly over the twoyear period. Furthermore, the data also contains other important information at the time of account origination, such as his personal income and wealth category (low, medium and high).

Equally important, our data also contains key information given by a borrower at the time of application that enables us to construct the individual social capital variables as outlined by Glaeser, Laibson, and Sacerdote (2002). If the credit cardholder has a spouse listed on the application, then we code her as married. Borrower age is determined from the birth date of the applicant. Homeownership is determined if the applicant has a mortgage balance reported at the credit bureau at the time of the credit card application. Based on the first three digits of the consumer's social security number, the state of birth of the applicant (and state of immigration entry for foreign born) can be identified. ${ }^{6}$ Since we also know the zip code at which the consumer currently lives, we create an indicator variable denoting that the consumer still lives in his "state of birth"; calculate the distance moved between state of birth and the currently reside zip code centroid (Distance Moved) ${ }^{7}$; and create an indicator variable denoting that the consumer moved to a rural area ${ }^{8}$.

\footnotetext{
${ }^{6}$ To convert the three digits into a state code, we follow the guidelines from the social security administration http://www.socialsecurity.gov/employer/stateweb.htm. We exclude $0.75 \%$ of the applicants since they did not match one of the 50 US states. For example, we exclude 534 consumers because the three digits of 580 and 586 represent Virgin Islands, Puerto Rico, Guam, American Samoa and Philippines. We exclude another 81 consumers because the three digits between 700-728 were assigned to railroad workers prior to 1964. Finally, we exclude 526 consumers because the first three digits were invalid.

${ }^{7}$ Distance moved between state and zip code centroid is calculated as follows:

Longitude to radians (if in decimal form omit the division by one million) $=($ longitude/1000000 $) *(\pi / 180)$

Latitude to radians (if in decimal form omit the division by one million) $=$
} 
To control for macroeconomic shocks and legal environments, we augment our loan-level data with county unemployment rate, as well as state-level demographics such as percentage of the state population without medical coverage. ${ }^{9}$ We also augment our data with state legal variables such as homestead and personal property exemption levels as well as garnishment rates. Since we do not know as to the exact date of the move to the current state, one potential reason for the move could be forum shopping for a potential bankruptcy filer - take advantage of the lenient exemption levels in the new state (Elul and Subramanian, 2002). Therefore, we include the change in the homestead and property exemptions levels, and the change in garnishment rates between a borrower's state of birth and the state which he currently lives in.

\subsection{Methodology}

Let $\mathrm{D}_{\mathrm{i}, \mathrm{t}}=1$ to indicate an account $i$ in bankruptcy or default in month $t$. Our data is a monthly discrete-time panel such that if, for example, the account becomes 90-days delinquent or the borrower files for bankruptcy in month 18 , then $\mathrm{D}_{\mathrm{i}, \mathrm{t}}=0$ for the first 17 months and $\mathrm{D}_{\mathrm{i}, 18}=1$, and the rest of the observations will drop out of the sample thereafter. ${ }^{10}$ We estimate the conditional probability that $\mathrm{D}_{\mathrm{i}}=1$ at time $t$, given that the consumer is current from the start of the performance period up to time $t-1$.

We estimate the following Cox proportional hazard model:

(latitude/1000000)*( $\pi / 180)$

Distance between two points, with both points' longitudes and latitudes in radians $=$ $\arccos (\sin ($ lat 1$) * \sin ($ lat 2$)+\cos ($ lat 1$) * \cos ($ lat 2$) * \cos (\operatorname{lon} 2-\operatorname{lon} 1)) * 6370 * 0.62$

${ }^{8} \mathrm{We}$ used the Metropolitan Statistical Area (MSA) definition.

${ }^{9}$ We also tried to control for state divorce rates; however, four states (California, Colorado, Indiana, and Louisiana) do not report divorce rate information whereas two other states (Nevada and Texas) do not have a complete time series for the time period covered in our study (see www.cdc.gov/nchs/nvss.htm). As discussed in the robustness section, including state divorce rates (without the six states) in our estimation, and our results remain the qualitatively similar.

${ }^{10}$ This common form of incomplete data is defined as right censored. Accordingly, all customers start at time $\mathrm{t}=0$ and a customer could drop out of the sample because they close the account in good standing or even stay current till the end of three years without being delinquent or declaring bankruptcy. We do not consider left censoring in our analysis (accounts that have already been delinquent or declared bankruptcy even before the observation of time begins). 


$$
h\left(t \mid X_{i, t}\right)=h_{0}(t) \exp \left(\beta X_{i, t}\right)
$$

Where $h\left(t \mid X_{i, t}\right)$ represents the probability the an individual will default on his credit debt or file for bankruptcy in month $t+1$, conditional on "surviving" up to month $t-1$. The baseline hazard function at month $\mathrm{t}$ is represented by $h_{0}(t)$, which does not take any specific functional form. The vector $X_{i, t}$ is comprised of time-varying as well as time-constant covariates as follows:

$$
\beta X_{i, t}=\beta_{1} \text { Time }_{t}+\beta_{2} \text { State }_{i}+\beta_{3} Y_{i, t}+\beta_{4} Z_{i, t}+\beta_{5} S_{i, t}+\beta_{6} L_{i, t}+\beta_{7} S C_{i}+\varepsilon_{i, t}
$$

$\beta$ is a vector of parameters to be estimated. The vector Time ${ }_{t}$ represents calendar month dummies to pick up any calendar time-effects. To account for possible systematic variations within a state, we estimate the above specification with state-fixed effects where State $_{i}$ is a vector of state dummies representing the credit cardholder's state of residence. As found in Domowitz and Sartain (1999), described in Sullivan et al (2002), and captured in the theoretical household default model of Chatterjee et al (2007), a debtor's decision to default or declare bankruptcy varies with his earnings, wealth and/or debt. Hence, the vector $Y_{i, t}$ captures the time-varying patterns of credit limit, spending, credit card debt, interest rate charge (APR) as well as other debt (including auto, mortgage or home equity credit), while the vector $Z_{i, t}$ represents income and wealth (reported at origination) as well as updated quarterly external credit risk score (see e.g., Gross and Souleles, 2002). The vector $S_{i, t}$ represents state-specific socio-economic characteristics such as county unemployment rates, and fraction of the state population without a health coverage. Several studies found that legal variables are predictive of bankruptcy, thus $L_{i, t}$ includes state-specific legal characteristics associated with consumer bankruptcy, including homestead and property exemption as well as garnishment rate. Fey et al. (2002) argued that controlling for exemption levels at the state level might be confounding with other state-specific events that are correlated with bankruptcy filings. Using the Panel Study of Income Dynamics (PSID), Elul and Subramanian (2002) found some evidence of forum shopping - 
that an individual's decision to migrate to a state with higher bankruptcy exemption levels is influenced by his propensity to file for bankruptcy, although the impact is modest. To address these potentials, we include the difference in the state bankruptcy exemption levels in a borrower's state of birth and the exemption levels in his current state of residence, after controlling for the state fixed effects.

Finally, the main variables of interest are represented by the vector $\mathrm{SC}_{\mathrm{i}}$, which captures the individual social capital formation characteristics at the opening of the credit card account. We mainly follow the economic approach to social capital formation set forth by Glaeser, Laibson and Sacerdote (2002) in which individuals accumulate social capital in the beginning of life as the return to such investment rises, but then reduce investment in social capital later in life as its return declines, thus our socio-economic characteristic includes the borrower's age and its square. Hence, we expect the risk of default or bankruptcy to decline in the early stage of life and then rise in the later stage of life - that is, we should find a U-shaped pattern of default or bankruptcy rate over the lifecycle. In addition, homeownership increases neighborhood social capital investment because high real estate transaction cost reduces mobility and homeowners have a financial incentive to increase their property value (see also DiPasquale and Glaeser, 1998). Hence, the vector $\mathrm{SC}_{\mathrm{i}}$ also includes an indicator variable denoting that the borrower is a homeowner, and another indicator variable denoting that the borrower is married. We expect the risk of default and bankruptcy to be lower for a debtor who owns a home or who is married.

Moreover, the vector $\mathrm{SC}_{\mathrm{i}}$ also captures mobility of a borrower: an indicator variable denoting that the borrower still lives in his state of birth, the distance the borrower has moved from his state of birth, and an indicator variable denoting that he moved to a rural area. Glaeser et al (2002) argue that the return to social capital investment depreciates when one moves out of a community; thus, 
mobility reduces the individual's social capital investment in a community. Frequent mobility also weakens social connection (see e.g., Glaeser and Sacerdote, 1999; Putnam, 2000) and reduces reputational concerns (see e.g., Buckley and Brinig, 2000). Hence, we expect the risk of default or bankruptcy to be lower for a borrower who continues to live in this state of birth or who moves to a rural area, and we expect the risk of default or bankruptcy to be higher with greater distance of mobility.

\section{Empirical Results}

\subsection{Cumulative Hazard Function}

We first use the semi-parametric model to estimate the baseline cumulative hazard function to understand the average default and bankruptcy rate over time and across the various measures of individual social capital formation. The semi-parametric modeling does not make any assumption about the parametric distribution of the survival times. Our baseline cumulative hazard function represent the cumulative rate of bankruptcy over account tenure, conditional on the mean values for all the independent variables over the analysis months. Figures 1-6 present the cumulative hazard functions by the various individual social capital formation variables.

Except for borrower age, the cumulative hazard functions indicate that default/bankruptcy rate is higher across account tenure for borrowers with individual social-economic characteristics that are predicted by Glaeser, Laibson and Sacerdote (2002) to have weaker incentive to invest in social capital. With respect to borrower age, the youngest (30 years or younger) and oldest (60 years or older) group of consumers has the lowest bankruptcy risk, while the middle age group of consumers has the highest rate of bankruptcy (Figure 1). This pattern is inconsistent to our expectation - that is, we expect lower risk of bankruptcy for the young and higher for the elders 
given greater incentive to invest in social capital in the early stage of life and weaker incentive to invest in social capital in the later stage of life.

As expected, homeowners have a lower bankruptcy rate than non-homeowners across account tenure (Figure 2), and married consumers also have a lower bankruptcy rate than single consumers (Figure 3). Moreover, Figure 4 indicates that a consumer who continues to live in his state of birth have lower bankruptcy risk, while a borrower who moved out of his state of birth has a higher bankruptcy risk. Figure 5 compares the cumulative hazard function by the distance of mobility. We categorize the distance moved into percentile. Consumers who moved from their state of birth but are within relatively closer proximity to their state of birth (below the $10^{\text {th }}$ percentile distance) have lower bankruptcy risk, while consumers who move farther from their state of birth (above the $90^{\text {th }}$ percentile distance) are more likely to file for bankruptcy. Furthermore, consumers who moved to a rural area have a lower rate of bankruptcy that those who move to an urban area (see Figure 6), which we define using the Metropolitan Statistical Area definition.

\subsection{Semi-Parametric Estimation Results}

Table 2 and 3 presents the results of the estimated Cox-proportional hazard model testing the impact of individual social capital variables on the likelihood of consumer default or bankruptcy. Before discussing the impact of social capital on bankruptcy and default, we first confer the impact of vital financial distress factors such as borrower riskiness, spending, debt, income, wealth as well as economic and legal environments on default or bankruptcy.

Our results indicate that the risk of credit card default or bankruptcy is significantly higher for consumers living in a county with higher unemployment rate ${ }^{11}$ as well as in a state with higher

\footnotetext{
${ }^{11}$ Agarwal and Liu (2003), who conduct an exhaustive analysis, also find that county unemployment rates to be a consistent and important predictor of credit card default.
} 
fraction of its population with no health insurance. Holding all other covariates at their mean value, a 1-percentage point increase in the county unemployment rate implies a 10 basis points increase in the likelihood of a borrower filing for bankruptcy. Equally important, the fraction of state population without health care coverage has a significantly positive but non-linear effect on bankruptcy (see Figure 7). Relative to an individual living in a state with only 5 percent of the state population without health care coverage, a borrower living in state with 10 percent of its people not having health care coverage is 34 basis points more likely to file for bankruptcy. On the other hand, relative to someone living in a state with 25 percent of the people without health insurance, a borrower living in a state with 30 percent of its population without health coverage is 135 basis points more likely to file for bankruptcy. These results are consistent with Gross and Souleles (2002), as well as with Domowitz and Sartain (1999) and Sullivan, Warren and Westbrook (2000) who document that unexpected medical debts is one of the most significant financial distress propelling households to file for bankruptcy.

Consumers who moved to a state with higher homestead and property exemption than their state of birth are statistically more likely to default or file for bankruptcy, albeit the economic impact is negligible (Figure 8 shows the relatively flat response of the predicted bankruptcy rate to changes in the difference of property exemptions). Consumers who moved to a state with lower garnishment rate than their state of birth are more likely to default or declare bankruptcy, but the marginal impact is small. Consistent with Elul and Subramanian (2002), our findings indicate that forum shopping has a trivial economic impact.

While our measure of both income and wealth are fairly noisy given that income is selfreported at the time of credit card account opening, they have significant predictive power. For example, compared to cardholders with low income those with high income and high wealth are 17 
and 22 percent, respectively, less likely to default on their debt. Similarly, compared to borrowers with low wealth, those with high wealth are 19 and 14 percent less likely to default their credit card debt and declare bankruptcy, respectively. These results are consistent with the bankruptcy filing properties captured in the dynamic equilibrium model of household default of Chatterjee, Corbae, Nakajima and Rios-Rull (2007).

In addition, borrowers who are less credit worthy (lower FICO risk score) are more likely to default on their credit debt and more likely to file for bankruptcy, consistent with findings in Gross and Souleles (2002) and Agarwal, Chomsisengphet, Liu and Souleles (2008). A 10-point drop in the FICO score implies a 4 percent increase in the likelihood of default and bankruptcy, holding all other covariates constant at their mean value. However, the negative relationship between FICO score and bankruptcy seems to be non-linear (see Figure 9), suggesting that the same 10-point drop of a FICO score of the less credit worthy borrowers (e.g., those with FICO $\leq 620)$ implies a larger increase in the risk of bankruptcy than the same point drop in the FICO score of the more credit worthy borrowers (e.g., those with FICO $\geq 740$ ). For example, the bankruptcy risk of a borrower whose FICO score declines from 600 to 580 jumps 46 basis points, while the bankruptcy risk of a borrower whose FICO score drops from 800 to 780 increases only 13 basis points.

Moreover, we also find that cardholders having lower credit limit but higher interest charges (APR), spending or debt (on this credit card) are more likely to default or file for bankruptcy. The risk of bankruptcy is 7 basis points higher when a borrower's APR increase from 15 to 25 percent and 32 basis points higher when the borrower's debt increases from $\$ 1000$ to $\$ 5000$ (see Figure 10). The explanatory significance of credit card debt and APR on consumer default and bankruptcy is consistent with evidence found in Domowitz and Sartain (1999) and documented in Sullivan, Warren and Westbrook (2000). On the other hand, our results also indicate that borrowers with 
higher other debt (including auto, mortgage and home equity credit) are significantly less likely to default on his this credit card debt and less likely to file for bankruptcy.

Finally, we turn to the impact of individual social capital characteristics on consumer bankruptcy or default outcomes. First, we find that credit card default and bankruptcy varies over the lifecycle - that is, the likelihood of default or bankruptcy rises with age in the early stage of life but then declines with age in the later stage of life (see Figure 11). While this inverted U-shaped pattern of bankruptcy rate over the lifecycle is inconsistent with our expectation based on the social capital formation framework of Glaeser, Laibson and Sacerdote (2002), it is consistent with the pattern depicted in Livshits, MacGee and Tertilt (2006). In addition, cardholder who owns a home or is married is 17 and 24 percent, respectively, less likely to default on his credit card, and is 25 and 32 percent, respectively, less likely to declare bankruptcy. These results are consistent with findings in Domowitz and Sartain (1999).

Moreover, we find that a cardholder who continues to live in his state of birth has a 14 percent lower probability of defaulting on his credit card debt and a 10 percent lower probability of declaring bankruptcy. Meanwhile, an individual who moves 325 miles from his state of birth is 26 percent more likely to default on his debt and 28 percent more likely to file for bankruptcy (see Figure 12). Finally, an individual moving to a rural area is 9 percent less likely to default on his debt and 7 percent less likely to file for bankruptcy. Given that the return to social capital investment declines with mobility (Glaeser, Laibson and Sacerdote, 2002), weakens social connection (see e.g., Glaeser and Sacerdote, 1999; Putnam, 2000) and reduces reputational concerns (see e.g., Buckley and Brinig, 2000), these results are consistent with our expectation based on the individual social capital formation economic model - that is, the risk of default or bankruptcy is lower for a borrower who has greater incentive to invest in social capital. 


\subsection{Extensions and Robustness}

Despite controlling for borrower credit worthiness, credit limit, APR, spending, debt, income, wealth as well as macroeconomic and legal environments, the explanatory significance of our individual social capital formation characteristics may be picking up the impact of other socioeconomic characteristics that are not included in our model, such as characteristics of people within each zip code that may also affect credit card default and personal bankruptcy. To address such concern, we estimated our model with zip code fixed effects (dropping state fixed effects). The results are shown in Table 3 and remain qualitatively consistent with those in Table 2, in which we used state fixed effects.

We also conducted exhaustive robustness checks on our analysis. First, we estimated the survival model with varying lag structure to alleviate any concerns that our results might be biased towards a particular lag length. Second, we also tried including state divorce rates (dropping three states that do not report divorce rate statistics). Third, we also tried including homestead and personal property exemption levels as well as garnishment rates (instead of the difference between the those of the borrower's state of birth and his state of residence as used in Table 2 and Table 3), dropping the state dummy variables since they do not very over time. Overall, the re-estimation results remain qualitatively consistent with the results being reported in Tables 2 and 3 .

\subsection{State-level Social Capital and Household Bankruptcy}

To further assess whether there's a connection between social capital and consumer bankruptcy at the community-level, we assess the correlation between Putnam's aggregate social 
capital index (Putnam 2000) and state bankruptcy filing rate in 2000. ${ }^{12}$ Putnam develops a social capital index based on 13 different measures of social capital like - membership in voluntary associations, attendance at club meetings, turnout at presidential elections, trust among individuals, and philanthropic generosity (among others).

We find a negative correlation of 0.4356 between Putnam's social capital index and state bankruptcy index. We find that states that are ranked higher on Putnam's social capital index (e.g., Vermont and Minnesota) have lower bankruptcy filing rate, while states that are ranked lower on the social capital index (e.g., Georgia and Tennessee) have higher bankruptcy rate (see Figure 13). We also regressed the state bankruptcy rates on Putnam's social capital index, controlling for the state's economic and legal characteristics. Table 4 reports the OLS regression results. We find that a 1point increase in the SCI results in a 0.3 points reduction in the state bankruptcy rate.

\section{Conclusion}

An individual's decision to maximize his investment in social capital is determined by his socio-economic characteristics (Glaeser, Laibson and Sarcerdote, 2002). In this paper, we empirically test the role of individual social capital formation characteristics on personal bankruptcy and default outcomes in the consumer credit market. After controlling for a borrower's riskiness, spending, debt, income, wealth as well as legal and economic environments, we find that individual social capital formation characteristics such as mobility, rural residency, homeownership, marital status, and borrower age play a statistically and economically significant role on consumer bankruptcy and defaults outcomes. These individual social capital formation characteristics collectively can affect the strength of a community's social networks and norms, and in turn shape

\footnotetext{
${ }^{12}$ The state bankruptcy rate per capita comes from the Administrative Office of the US Courts and the US Bureau of the Census, and is ranked to construct state bankruptcy index.
} 
the degree of a community's attitude towards certain socio-economic behaviors or outcomes. Therefore, the explanatory significance of an individual's social capital formation characteristics on his need to default on his debt or to file for bankruptcy could perhaps provide additional insights to the role of social stigma on consumer bankruptcy.

Our study also has some direct policy implications. The recent signing of the Bankruptcy Abuse Prevention and Consumer Protection Act of 2005 by President George W. Bush on April $20^{\text {th }}$ 2005 aims to reduce a debtor's inability to take advantage of what was considered lenient bankruptcy laws and make "fresh start" unavailable for bankruptcy filers unless their household income is below the median level in their state of residence. As in Elul and Subramanian (2002), our results suggest that state bankruptcy laws have negligible economic impact on a consumer's propensity to file for bankruptcy. Our findings suggest that while lenient bankruptcy laws have statistical impact on consumer bankruptcy, other vital financial distress factors such as lower income, lower wealth, unemployment and not having health insurance coverage play a more economically prominent role in consumers' need to file for bankruptcy, which are generally consistent with the predictions captured in the theoretical default model of Chatterjee, Corbae, Nakajima and Rios-Rull (2007) and the evidence provided by Sullivan, Warren and Westbrook (2000) and Gross and Souleles (2002). Hence, without effective policies to also ensure health care coverage, stimulate local economic growth and uphold real wage increase, tightening bankruptcy laws could have feeble impact on reducing bankruptcy filings. 


\section{References}

Abreu, D. 1988. "On the Theory of Infinitely Repeated Games with Discounting," Econometrica 56(2): 383-396.

Agarwal, S., S. Chomsisengphet, C. Liu and N. Souleles. 2008. "Benefits of Relationship Banking: Evidence from Consumer Credit Markets, mimeo, Wharton.

Agarwal, S., S. Chomsisengphet, C. Liu, and L. Mielnicki. 2005. "Impact of State Exemption Laws on Small Business Bankruptcy Decision,” Southern Economic Journal 71(3): 620-635.

Agarwal, S., C. Liu, and L. Mielnicki. 2003. "Exemption Laws and Consumer Delinquency and Bankruptcy Behavior: An Empirical Analysis of Credit Card Data," Quarterly Review of Economics and Finance 43(2): 273-289.

Alesina, A., and E. LaFerrara. 2000. "Participation in Heterogeneous Communities," Quarterly Journal of Economics 115(3): 847-904.

Arrow, K. 1972. "Gifts and Exchanges,” Philosophy and Public Affairs 1: 342-362.

Athreya, K. 2004. "Shame As It Ever Was: Stigma and Personal Bankruptcy," Federal Reserve Bank of Richmond Economic Quarterly, 90(2): 1-19.

Barron, J., G. Elliehausen and M. Staten. 2000. Monitoring the Household Sector with Aggregate Credit Bureau Data, Business Economics 35(1): 63-76.

Buckley, F.H. and M.F. Brinig. 1998. “The Bankruptcy Puzzle,” Journal of Legal Studies 82: 187207.

Chatterjee, S., D. Corbae, M. Nakajima, and JV. Rios-Rull. 2007. “A Quantitative Theory of Unsecured Consumer Credit With Risk of Default," forthcoming Econometrica.

DiPasquale, D., and E. Glaeser. 1999. "Incentives and Social Capital: Are Homeowners Better Citizens?" Journal of Urban Economics 45: 354-384.

Domovitz, I., and R.L. Sartain. 1999. "Determinants of the Consumer Bankruptcy Decision," Journal of Finance 54(1): 403-420.

Elul, R. and N. Subramanian. 2002. "Forum-Shopping and Personal Bankruptcy," Journal of Financial Services Research 21: 233-255

Fay, S., E. Hurst, and M. J. White. 2002. "The Household Bankruptcy Decision,” American Economic Review 92(3): 706-718.

Glaeser, E., D. Laibson, and B. Sacerdote. 2002. "The Economic Approach to Social Capital,” The Economic Journal 112: 437-458. 
Glaeser, E., and B. Sacerdote. 2000. "The social consequences of housing," Journal of Housing Economics 9: 1-23.

Greif, A. 1993. "Contract Enforceability and Economic Institutions in Early Trade: the Maghribi's Traders' Coalition," American Economic Review 83(3): 525-548.

Gropp, P. J., K. Scholz, and M. J. White. 1997. "Personal Bankruptcy and Credit Supply and Demand," Quarterly Journal of Economics 112(1): 217-251.

Gross, D. B., and N. S. Souleles. 2002. "An Empirical Analysis of Personal Bankruptcy and Delinquency,” Review of Financial Studies 15(1): 319-347.

Guiso, L., P. Sapienza, L. Zingales. 2004. "The Role of Social Capital in Financial Development," American Economic Review 94(3): 526-556.

Hong, H., J. Kubik, and J. Stein. 2004. "Social Interaction and Stock-Market Participation,” Journal of Finance LIX(1): 137-163.

Knack, S., and P. Keefer. 1997. "Does Social Capital Have an Economic Payoff? A Cross-Country Investigation," Quarterly Journal of Economics 112(4): 1251-1288.

LaPorta, R., F Lopez-de-Silanes, A. Shleifer, and R. Vishny. 1997. "Trust in Large Organizations," American Economic Review 87(2): 333-338.

Livshits, I., J. MacGee, and M. Tertilt. 2007. “Accounting for the Rise in Consumer Bankruptcies," NBER Working Paper 13363.

Madrian, B., and D. Shea. 2001., "The Power of Suggestion: Inertia in 401(k) Participation and Savings Behavior," Quarterly Journal of Economics 116(4): 1149-1187.

Putnam, R. 1995. "Bowling Alone: America's Declining Social Capital" Journal of Demography 6: 65-78.

Putnam, R. 2000. Bowling Alone: The Collapse and Revival of American Community, Paperback Edition. Simon \& Schuster.

Sullivan, T., E. Warren, and J. Westbrook. 2000. The Fragile Middle Class: Americans in Debt, Yale University Press, New Haven and London. 
Table 1: Summary Statistics

\begin{tabular}{|c|c|c|}
\hline Variables & Mean & Std. Dev. \\
\hline \multicolumn{3}{|l|}{ Macro and "Trigger" Event Variables } \\
\hline Unemploymentt & 4.72 & 1.01 \\
\hline$\%$ With No Health Care Coverage & 14.63 & 4.29 \\
\hline \multicolumn{3}{|l|}{ Legal Variables } \\
\hline Property Exemptions & $\$ 9,824$ & $\$ 6,887$ \\
\hline Homestead Exemptions & $\$ 205,456$ & $\$ 377,166$ \\
\hline Garnishment & $18 \%$ & $10 \%$ \\
\hline Change in Property Exemptions & $\$ 2,285$ & $\$ 5,394$ \\
\hline Change in Homestead Exemptions & $\$ 24,947$ & $\$ 308,622$ \\
\hline Change in Garnishment & $50 \%$ & $77 \%$ \\
\hline \multicolumn{3}{|l|}{ Borrower Credit Risk Variables } \\
\hline Income & $\$ 56,636$ & $\$ 110,222$ \\
\hline Income Low & $29 \%$ & $39 \%$ \\
\hline Income Medium & $50 \%$ & $50 \%$ \\
\hline Income High & $21 \%$ & $41 \%$ \\
\hline Wealth Low & $31 \%$ & $29 \%$ \\
\hline Wealth Medium & $59 \%$ & $53 \%$ \\
\hline Wealth High & $10 \%$ & $21 \%$ \\
\hline FICO & 713 & 72 \\
\hline APR & 18.16 & 6.41 \\
\hline Credit Line & $\$ 7,408$ & $\$ 3,404$ \\
\hline Debt & $\$ 2,232$ & $\$ 2,915$ \\
\hline Spending & $\$ 235$ & $\$ 763$ \\
\hline Total Credit Card Balances (Spending) & $\$ 9,167$ & $\$ 13,563$ \\
\hline Home Equity Balance & $\$ 2,805$ & $\$ 14,102$ \\
\hline Mortgage Balance & $\$ 52,826$ & $\$ 91,273$ \\
\hline Auto Balance & $\$ 4,541$ & $\$ 7,892$ \\
\hline Credit Bureau Balance (Other Debt) & $\$ 69,339$ & $\$ 98,166$ \\
\hline \multicolumn{3}{|l|}{ Social Capital Variables } \\
\hline Borrower Age & 48.71 & 13.95 \\
\hline Own Home & $48 \%$ & $50 \%$ \\
\hline Married & $64 \%$ & $47 \%$ \\
\hline Live in the State Where Born & $35 \%$ & $48 \%$ \\
\hline Ln(Distance Moved) & 5.25 & 1.16 \\
\hline Move to Rural Area & $26 \%$ & $19 \%$ \\
\hline Own Home * Live in the State Where Born & $31 \%$ & $46 \%$ \\
\hline Own Home * Log(Distance Moved $)$ & 2.52 & 2.75 \\
\hline Number of Observations & 3.2 Million & \\
\hline Number of Accounts & 170793 & \\
\hline
\end{tabular}


Table 2: Proportional Hazard Results for Consumer Default and Bankruptcy

\begin{tabular}{|c|c|c|c|c|c|c|c|c|}
\hline \multirow[t]{2}{*}{ Variables } & \multicolumn{4}{|c|}{ Default } & \multicolumn{4}{|c|}{ Bankruptcy } \\
\hline & Coeff & Std Err & P-value & Marg Eff & Coeff & Std Err & P-value & Marg Eff \\
\hline \multicolumn{9}{|l|}{ Macro and "Trigger" Event Variables } \\
\hline UnemploymentRate $_{t-6}$ & 0.07932 & 0.01163 & 0.0002 & $7.29 \%$ & 0.07680 & 0.01088 & $<.0001$ & $7.86 \%$ \\
\hline $\begin{array}{c}\% \text { With No Health Care Coverage } \mathrm{t}_{\mathrm{t}-6} \\
\text { Legal Variables }\end{array}$ & 0.06246 & 0.02174 & 0.0041 & $0.83 \%$ & 0.07149 & 0.02890 & 0.01632 & $0.70 \%$ \\
\hline Difference in Property Exemptions $\mathrm{t}_{\mathrm{t} 0}$ & 0.00000 & 0.00000 & $<.0001$ & $0.00 \%$ & 0.00001 & 0.00001 & 0.1237 & $0.00 \%$ \\
\hline Difference in Homestead Exemptions $\mathrm{t}_{\mathrm{t} 0}$ & 0.00000 & 0.00000 & $<.0001$ & $0.00 \%$ & 0.00000 & 0.00000 & 0.2506 & $0.00 \%$ \\
\hline Difference in Garnishment $t_{0}$ & -0.00175 & 0.00018 & $<.0001$ & $-0.02 \%$ & -0.00165 & 0.00334 & 0.6204 & $-0.01 \%$ \\
\hline \multicolumn{9}{|l|}{ Borrower Risk Characteristics } \\
\hline Income Medium $_{\mathrm{t} 0}$ & -0.08916 & 0.03085 & $<.0001$ & $-8.08 \%$ & -0.07986 & 0.02092 & $<.0001$ & $-7.57 \%$ \\
\hline Income $\mathrm{High}_{\mathrm{t} 0}$ & -0.19291 & 0.04922 & $<.0001$ & $-16.71 \%$ & -0.24816 & 0.06388 & $<.0001$ & $-21.71 \%$ \\
\hline Wealth Medium t0 $_{0}$ & -0.10337 & 0.05779 & $<.0001$ & $-9.31 \%$ & -0.06873 & 0.02980 & $<.0001$ & $-6.55 \%$ \\
\hline Wealth $\mathrm{High}_{\mathrm{t} 0}$ & -0.22011 & 0.07720 & $<.0001$ & $-18.87 \%$ & -0.14920 & 0.05234 & $<.0001$ & $-13.67 \%$ \\
\hline $\mathrm{FICO}_{\mathrm{t}-6}$ & -0.00681 & 0.00017 & $<.0001$ & $-0.40 \%$ & -0.00672 & 0.00031 & $<.0001$ & $-0.42 \%$ \\
\hline $\mathrm{APR}_{\mathrm{t}-6}$ & 0.37270 & 0.02373 & $<.0001$ & $4.93 \%$ & 0.47724 & 0.04772 & $<.0001$ & $6.87 \%$ \\
\hline Credit Line t -6 & -0.00018 & 0.00001 & $<.0001$ & $0.00 \%$ & -0.00032 & 0.00001 & $<.0001$ & $0.00 \%$ \\
\hline Spending $_{\mathrm{t}-6}$ & 0.00000 & 0.00000 & $<.0001$ & $0.05 \%$ & 0.00002 & 0.00000 & $<.0001$ & $0.03 \%$ \\
\hline Credit Card Debt $t_{\mathrm{t}-6}$ & 0.00002 & 0.00000 & 0.0127 & $0.00 \%$ & 0.00005 & 0.00000 & $<.0001$ & $0.00 \%$ \\
\hline Credit Bureau Balance (Other Debt) $)_{t-6}$ & -0.00001 & 0.00000 & $<.0001$ & $0.00 \%$ & -0.00001 & 0.00000 & 0.0938 & $0.00 \%$ \\
\hline \multicolumn{9}{|l|}{ Social Capital Variables } \\
\hline Borrower Age $_{\mathrm{t} 0}$ & 0.06522 & 0.00337 & $<.0001$ & $4.93 \%$ & 0.04022 & 0.00680 & $<.0001$ & $3.93 \%$ \\
\hline Borrower Age-Sq $\mathrm{ft}_{0}$ & -0.00051 & 0.00003 & $<.0001$ & $-2.30 \%$ & -0.00033 & 0.00006 & $<.0001$ & $-1.29 \%$ \\
\hline Own Home $_{\text {t0 }}$ & -0.19416 & 0.01182 & $<.0001$ & $-16.56 \%$ & -0.28313 & 0.03111 & $<.0001$ & $-24.82 \%$ \\
\hline Married $_{t 0}$ & -0.27610 & 0.02444 & $<.0001$ & $-23.80 \%$ & -0.42058 & 0.04435 & $<.0001$ & $-31.77 \%$ \\
\hline Living in the State of Birth $\mathrm{t}_{\mathrm{t}}$ & -0.14940 & 0.04581 & 0.0019 & $-13.89 \%$ & -0.10477 & 0.08108 & 0.0013 & $-9.81 \%$ \\
\hline Log(Distance Moved $)_{\mathrm{t} 0}$ & 0.23920 & 0.01978 & 0.0041 & $26.20 \%$ & 0.25757 & 0.03444 & 0.0042 & $27.91 \%$ \\
\hline Move to Rural Area $\mathrm{t}_{0}$ & -0.10899 & 0.02561 & $<.0001$ & $-9.30 \%$ & -0.08482 & 0.09098 & $<.0001$ & $-7.33 \%$ \\
\hline Own Home * Live in the State Where Born ${ }_{\mathrm{t} 0}$ & -0.08692 & 0.03690 & 0.0482 & $-1.60 \%$ & -0.09299 & 0.04729 & 0.0284 & $-1.93 \%$ \\
\hline Own Home $* \log (\text { Distance Moved })_{\mathrm{t} 0}$ & -0.05175 & 0.02766 & 0.0284 & $-3.70 \%$ & -0.04486 & 0.01787 & 0.0184 & $-1.60 \%$ \\
\hline 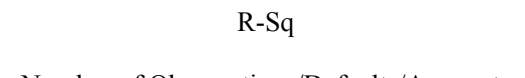 & $\begin{array}{c}18.48 \% \\
3.2\end{array}$ & & & & $\begin{array}{c}20.10 \% \\
3.2\end{array}$ & & & \\
\hline Number of Observations/Defaults/Accounts & Million & 9288 & 170793 & & Million & 2504 & 170793 & \\
\hline Time Fixed Effects (19 months) & YES & & & & YES & & & \\
\hline State Fixed Effects (50 states) & YES & & & & YES & & & \\
\hline Clustered Standard Errors & Individual & & & & Individual & & & \\
\hline
\end{tabular}

Notes: The table reports results of a hazard model of consumer default using monthly account level data from June 2000 to June 2002 . Explanatory variables include: legal factors (garnishment, property and homestead exemptions); macroeconomic risk factors (county unemployment, percentage of consumer without health insurance in a state); account-specific risk factors (income, wealth, FICO score, credit line amount, spending, credit card debt, and other debt which may include mortgage, home equity or auto); and individual social characteristics (borrower age, home ownership status, marital status, distance moved from the state of birth, living in state of birth indicator, and move to rural indicator); local risk factors - state dummies and calendar time dummies. Subscript $\mathrm{t}-6$ represents the control variables six months prior to default and t0 represents control variable at June 2000 . 
Table 3: Proportional Hazar Model of Consumer Default and Bankruptcy

\begin{tabular}{|c|c|c|c|c|c|c|c|c|}
\hline \multirow[t]{2}{*}{ Variables } & \multicolumn{4}{|c|}{ Default } & \multicolumn{4}{|c|}{ Bankruptcy } \\
\hline & Coeff & Std Err & P-value & Marg Eff & Coeff & Std Err & P-value & Marg Eff \\
\hline \multicolumn{9}{|l|}{ Macro and "Trigger" Event Variables } \\
\hline UnemploymentRate $_{\mathrm{t}-6}$ & 0.06500 & 0.01052 & 0.0037 & $5.83 \%$ & 0.06171 & 0.00952 & 0.0001 & $6.22 \%$ \\
\hline $\begin{array}{c}\% \text { With No Health Care Coverage } \mathrm{t}_{\mathrm{t}-6} \\
\text { Legal Variables }\end{array}$ & 0.06568 & 0.02573 & 0.0107 & $0.53 \%$ & 0.06565 & 0.05093 & $<.0001$ & $0.63 \%$ \\
\hline Difference in Property Exemptions $\mathrm{E}_{\mathrm{t} 0}$ & 0.00000 & 0.00000 & $<.0001$ & $0.00 \%$ & 0.00002 & 0.00001 & 0.0032 & $0.00 \%$ \\
\hline Difference in Homestead Exemptions $\mathrm{s}_{\mathrm{t} 0}$ & 0.00000 & 0.00000 & $<.0001$ & $0.00 \%$ & 0.00000 & 0.00000 & $<.0001$ & $0.00 \%$ \\
\hline $\begin{array}{c}\text { Difference in Garnishment }{ }_{t 0} \\
\text { Borrower Credit Risk Variables }\end{array}$ & -0.00046 & 0.00016 & $<.0001$ & $-0.02 \%$ & -0.00845 & 0.00518 & $<.0001$ & $-0.03 \%$ \\
\hline Income Medium ${ }_{\mathrm{t} 0}$ & -0.07284 & 0.03074 & $<.0001$ & $-6.49 \%$ & -0.06832 & 0.02745 & $<.0001$ & $-6.47 \%$ \\
\hline Income $\mathrm{High}_{\mathrm{t} 0}$ & -0.18023 & 0.05023 & $<.0001$ & $-15.36 \%$ & -0.20586 & 0.05787 & $<.0001$ & $-18.26 \%$ \\
\hline Wealth Medium $_{t 0}$ & -0.08230 & 0.03682 & $<.0001$ & $-7.30 \%$ & -0.05490 & 0.02034 & 0.0010 & $-5.23 \%$ \\
\hline Wealth High $_{\mathrm{t} 0}$ & -0.20820 & 0.04821 & $<.0001$ & $-17.56 \%$ & -0.12048 & 0.05822 & 0.0001 & $-11.13 \%$ \\
\hline $\mathrm{FICO}_{\mathrm{t}-6}$ & -0.00665 & 0.00024 & $<.0001$ & $-0.63 \%$ & -0.00675 & 0.00047 & $<.0001$ & $-0.47 \%$ \\
\hline $\mathrm{APR}_{\mathrm{t}-6}$ & 0.37735 & 0.02747 & $<.0001$ & $5.82 \%$ & 0.57127 & 0.07463 & $<.0001$ & $7.02 \%$ \\
\hline Credit Line ${ }_{t-6}$ & -0.00020 & 0.00001 & $<.0001$ & $0.00 \%$ & -0.00032 & 0.00001 & $<.0001$ & $0.00 \%$ \\
\hline Spending ${ }_{t-6}$ & 0.00000 & 0.00000 & $<.0001$ & $0.03 \%$ & 0.00000 & 0.00000 & $<.0001$ & $0.03 \%$ \\
\hline Debt $_{t-6}$ & 0.00000 & 0.00000 & 0.0004 & $0.00 \%$ & 0.00000 & 0.00000 & 0.0098 & $0.00 \%$ \\
\hline \multicolumn{9}{|l|}{ Social Capital Variables } \\
\hline Borrower Age $_{t 0}$ & 0.06498 & 0.00511 & $<.0001$ & $2.80 \%$ & 0.04600 & 0.01063 & $<.0001$ & $2.99 \%$ \\
\hline Borrower Age-Sq $\mathrm{t}_{\mathrm{t} 0}$ & -0.00055 & 0.00004 & $<.0001$ & $-1.70 \%$ & -0.00038 & 0.00009 & $<.0001$ & $-1.02 \%$ \\
\hline Own Home $\mathrm{t}_{0}$ & -0.14768 & 0.05493 & $<.0001$ & $-13.29 \%$ & -0.24263 & 0.46540 & $<.0001$ & $-22.08 \%$ \\
\hline Married $_{t 0}$ & -0.19630 & 0.03568 & $<.0001$ & $-17.79 \%$ & -0.30671 & 0.06817 & $<.0001$ & $-26.92 \%$ \\
\hline Live in the State Where Born ${ }_{t 0}$ & -0.14260 & 0.07250 & 0.0493 & $-12.60 \%$ & -0.09928 & 0.13867 & $<.0001$ & $-9.32 \%$ \\
\hline $\log (\text { Distance Moved })_{t 0}$ & 0.20624 & 0.03330 & 0.0219 & $22.11 \%$ & 0.23844 & 0.06266 & $<.0001$ & $25.82 \%$ \\
\hline Move to Rural Area $a_{t 0}$ & -0.07146 & 0.03206 & $<.0001$ & $-6.90 \%$ & -0.07424 & 0.57903 & $<.0001$ & $-6.79 \%$ \\
\hline Own Home * Live in the State Where Born ${ }_{t 0}$ & -0.49028 & 0.09207 & $<.0001$ & $-2.50 \%$ & -0.27303 & 0.07259 & $<.0001$ & $-2.70 \%$ \\
\hline Own Home $* \log (\text { Distance Moved })_{t 0}$ & -0.54900 & 0.03794 & $<.0001$ & $-5.90 \%$ & -0.52089 & 0.07116 & $<.0001$ & $-5.47 \%$ \\
\hline $\mathrm{R}-\mathrm{Sq}$ & $23.64 \%$ & & & & $28.55 \%$ & & & \\
\hline $\begin{array}{l}\text { Number of Observations/Defaults } \\
\text { Time Fixed Effects (19 months) }\end{array}$ & $\begin{array}{l}\text { 3.2 Million } \\
\text { YES }\end{array}$ & 9288 & 170793 & & $\begin{array}{l}\text { 3.2 Million } \\
\text { YES }\end{array}$ & 2504 & 170793 & \\
\hline Zip Code Fixed Effects (21127 zipcodes) & YES & & & & YES & & & \\
\hline Clustered Standard Errors & Individual & & & & Individual & & & \\
\hline
\end{tabular}

Notes: The table reports results of a hazard model of consumer default using monthly account level data from June 2000 to June 2002. Explanatory variables include: legal factors (garnishment, property and homestead exemptions); macroeconomic risk factors (county unemployment, percentage of consumer without health insurance in a state); account-specific risk factors (income, wealth, FICO score, credit line amount, spending, credit card debt, and other debt which may include mortgage, home equity or auto); and individual social characteristics (borrower age, home ownership status, marital status, distance moved from the state of birth, living in state of birth indicator, and move to rural indicator); local risk factors - state dummies and calendar time dummies. Subscript t-6 represents the control variables six months prior to default and t0 represents control variable at June 2000. 
Table 4: State Bankruptcy Rates and State Social Capital Index in 2000

\begin{tabular}{c|ccc}
\hline Variables & Coeff & Std Err & t-stat \\
\hline Intercept & 9.277720 & 4.798880 & 1.93 \\
Social Capital Index & -0.300690 & 0.152520 & -1.97 \\
Homestead Exemptions & -0.000003 & 0.000005 & -0.52 \\
Property Exemptions & 0.000007 & 0.000343 & 0.02 \\
Garnishment & -0.370800 & 0.213680 & -1.74 \\
\% With No Health Care Coverage & 1.203840 & 0.525100 & 2.29 \\
Unemployment Rate & 3.825380 & 1.401090 & 2.73 \\
\hline Adjusted R-Sq & $36.96 \%$ & & \\
\hline Number of Observations & 48 & &
\end{tabular}



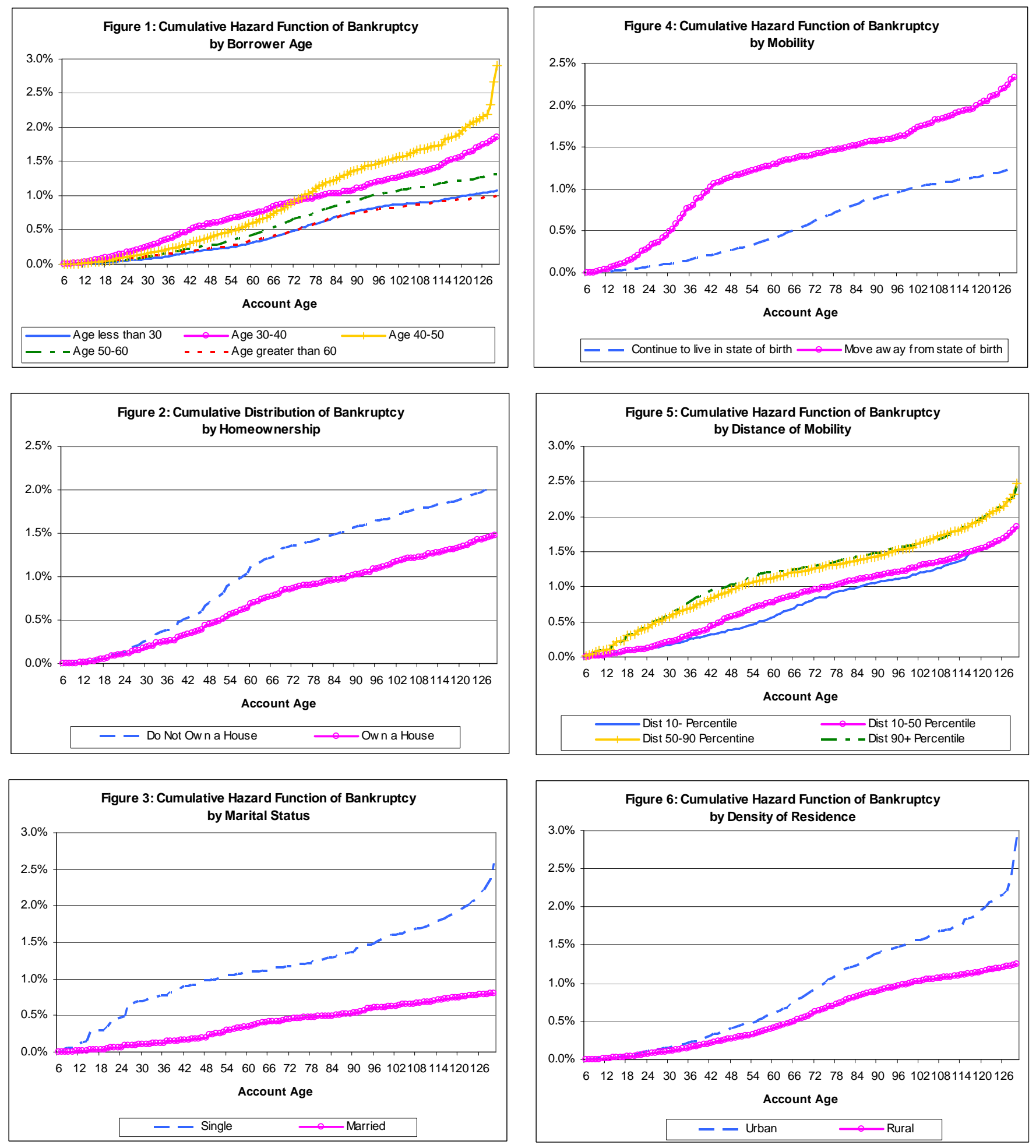

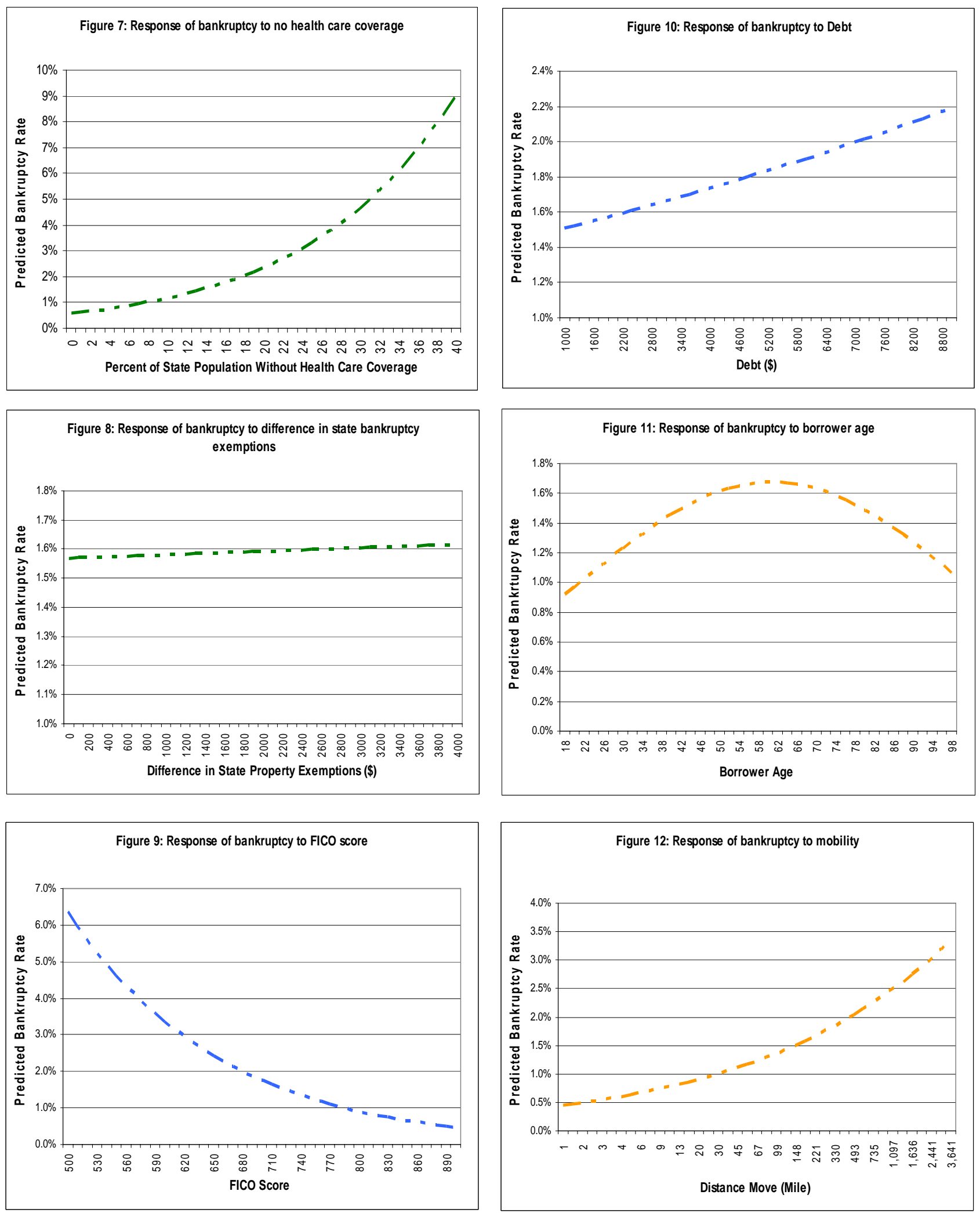

Figure 13: Correlation between social capital index and state bankruptcy index in 2000

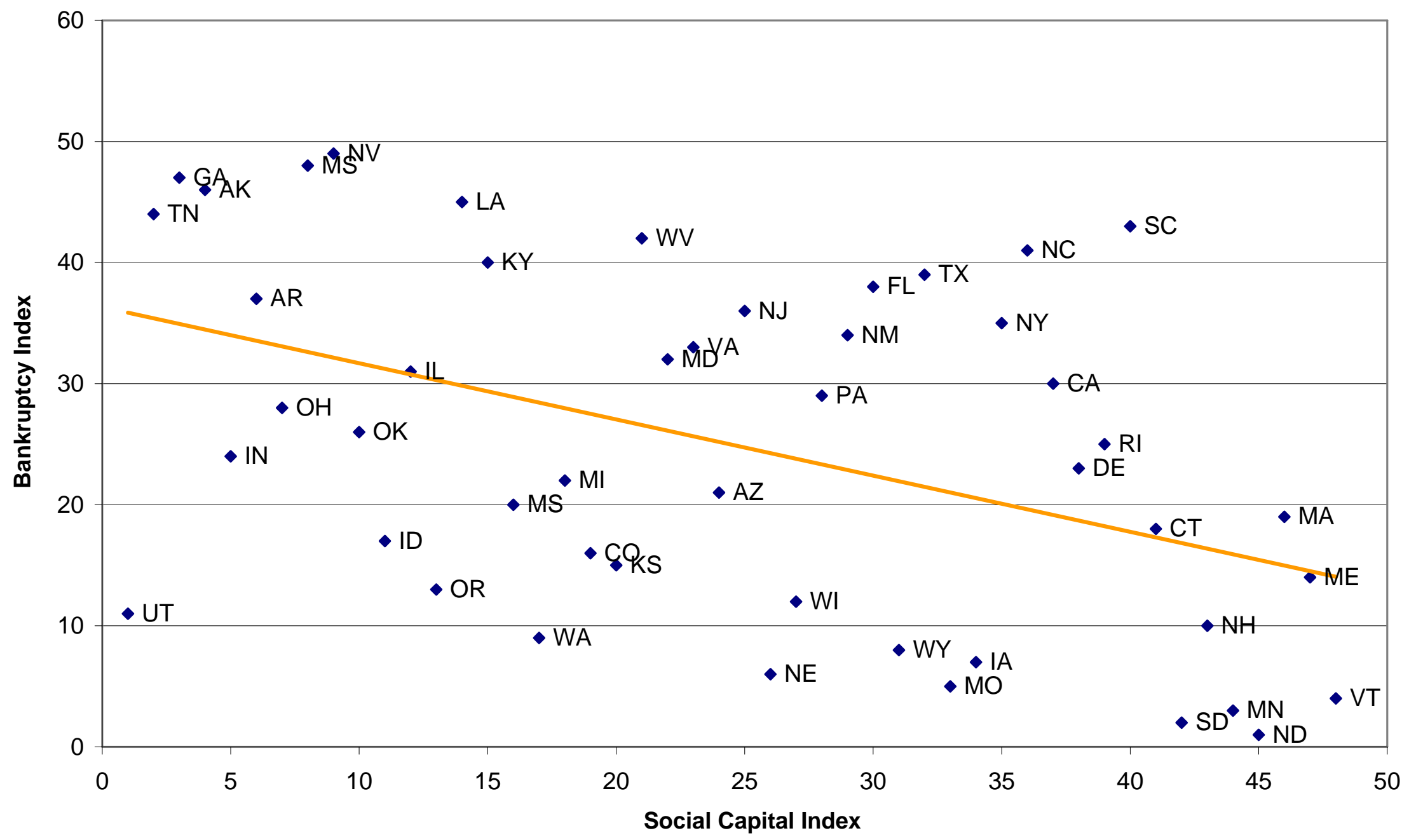

